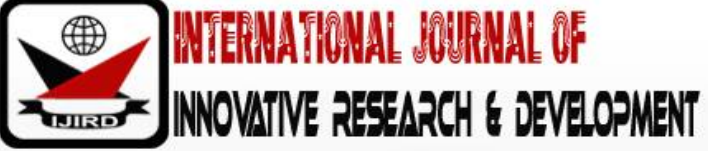

ISSN 2278 - 0211 (Online)

\section{Major Risk Components and Performance of Deposit Money Banks (DMBs) in Nigeria}

\author{
Dr. Ogbonna Udochukwu Godfrey \\ Executive Chairman, Abia State Internal Revenue Service, Nigeria \\ Ejem Chukwu Agwu \\ Lecturer, Abia State Polytechnic, Abia, State, Nigeria
}

\begin{abstract}
:
This study examines the effects of credit and liquidity risks on performance of deposit money banks in Nigeria using aggregated time series data within the ARDL framework from 1990 to 2016. While credit risk is defined as the ratio of non-performing loans to total loans, liquidity risk is measured by average liquidity ratio. Bank performance is measured by return on assets. The results show that bank performance is autoregressive such that a $1 \%$ increase in return on assets in the current period would lead to approximately $33 \%$ increase in the next period return on assets. Further, the results show that while non-performing loan has highly significant contemporaneous and lagged effects on return on assets, the effect of average liquidity ratio is insignificant. Thus, bank performance is only affected by credit risks. We therefore argue that focusing on credit risk management would be healthy in the Nigerian banking system.
\end{abstract}

Keywords: Banks performance, credit risk, liquidity risk, ARDL.

\section{Introduction}

Risk management in the banking sector has continued to be a major concern for policy makers and researchers, especially after the global financial crisis. Risk Management is the identification, assessment and prioritization of risks followed by coordinated and economical application of resources to minimize, monitor, and control the probability and/ or impact of unfortunate events (Njogo, 2012).It is neither a concept for complete risk avoidance nor its elimination. The essential functions of risk management are to identify, measure and more importantly monitor the profile of the bank. While for example, non-performing assets are the legacy of the past in the present, risk management system is the proactive action in the present for the future.

It is important to note that a bank that is run on the principle of avoiding all risks or as many of them as are possible, will not be dynamic and may not adequately serve the credit needs of its customers and the demands of economic development. On the other hand, a bank that takes excessive risks would actively run into crisis-liquidity and capital adequacy problem. Thus, the overall consideration of bank management is minimizing risks and maximizing returns, consistent with prudential constraints and regulations. Thus, risk management must be compatible with profitability, liquidity and prudential requirements (Nwankwo, 1991; Nzotta, 2002).

One important dimension of risk management is credit risk management. Credit risk, according to Basel Committee of Banking Supervision Basel Committee on Banking Supervision (2001) and Gostineau (1992), is the possibility of losing the outstanding loan partially or totally, due to credit events (default risk), failure to pay a due obligation, repudiation/moratorium or credit rating change and restructure. Bessis (2002) opined that credit risk is critical since the default of a small number of important customers can generate large losses, which can lead to insolvency. This is because financial firms tend to hold little owners' capital relative to the aggregate value of their assets, only a small percentage of total loans needs to turn bad to push them to the brink of failure.

Another important dimension of risk management is liquidity risk management. Nwankwo (1991) a liquidity risk arises when a bank finds itself unable to meet its commitments when due and to undertake new transactions when desirable. In recent years, the CBN has expressed concerns about both liability side and asset side (loan commitment) liquidity risk. When liability holders demand cash immediately- that is, 'put' their financial claim back to the financial institution- financial institution must either borrow additional funds or sell assets to meet the demand for the withdrawal of funds. According to Rose and Hudgins (2010), financial services managers are also concerned about the danger of not having sufficient cash and borrowing capacity to meet customer withdrawals, loan demand, and other cash needs. Faced with liquidity risk a financial institution may be forced to borrow emergency funds at the excessive cost of cover its immediate cash needs, reducing its earnings.

Owojori, Akintoye and Adidu (2011) contended that banking crises in Nigeria have shown that not only do banks often take excessive risks but the risks differ across banks. Some banks engage in more risks than their capital could bear. 
Other banks are more prudent and would be able to contain a banking crisis. In a bid to strengthen the system, the Central Bank of Nigeria (CBN) on July 6, 2004, introduced measures to ensure that the entire banking system is safe, bound, stable environment that could sustain public confidence (which Nwankwo 1991 viewed as its cornerstone). According to the presiding CBN government at the time, Prof Chukwuma Soludo said, it is now time to set up a structure that creates a strong base relative to the kind of economy we are operating where banks become channels to do proper intermediation. (The Obasanjo Economic Reforms on the Banking Sector, 2005).

The essence of the reform policy was to consolidate the banking institutions through mergers and acquisitions (the Obasanjo Economic Reforms, 2005). At the moment, the policy seemed to have raised some dusts and generated some debates among experts and from different strata of the Nigerian society. Hitting the deadline, December 31, 2005, 25 out of 89 commercial banks operating in the country emerged consolidated through recapitalization to the tune of 25 billion. Some consolidated through mergers while others were acquired (Ejem, 2017). In the words of Ejem (2017), it is pertinent at this point to emphasize that since the emergence of 25 consolidated commercial banks in Nigeria in 2005, now about 21 banks, the industry players and other stockholders have been faced with how best to manage the post-consolidation challenges, that confront the Nigeria banking industry and the economy. This, according to Owojori, Akintoye and Adidu (2011), is compelling reason operators of the banking system in Nigeria are challenged to take more seriously the important issue of risk acceptance/ rejection, which is often the point at which bankers fall into or escape the trap of greed.

Meanwhile, in a bid to enhance the confidence and trust of depositors on the banking business, the CBN from time to time brings out regulatory measures to consolidate the banking sector. For example, CBN pronounced a 13-point agenda to stabilize the base of the banking industry. The key elements in the agenda included among others the compulsory recapitalization of 25 billion for a commercial bank operating in the country with deadline of December 31 , 2005. The essence of the reform policy was to consolidate the banking institutions through mergers and acquisitions and to ensure that the entire banking system is safe, bound, stable environment that could sustain public confidence. The essence of these measures is to forestall or ameliorate mostly credit risk and liquidity risk. The two major risks and others are still masquerading and critically affect the performance of the commercial banks despite the regulatory measures on ground by the CBN.

This study therefore examines the effect of credit and liquidity risks as major components of risk on the performance of commercial banks in Nigeria from 1990 to 2016 using the ARDL methodological framework. The current study is distinct in the sense that its empirical analysis is based on time series framework using aggregated time series data. Previous studies in this line of research are mostly based on panel data framework using disaggregated data. It is therefore our view that using aggregated data would provide an empirical insight on the nature of the relationship between credit and liquidity risks and bank performance.

The remainder of this study has the following structure. Section 2 reviews some empirical studies that are relevant to the current study. Section 3 focuses on the research methodology. Section 4 contains data analysis and results while section 5 concludes the study.

\section{Review of Some Empirical Studies}

Halim (2004) investigated empirically on interest rate and exchange rate exposures of banking institutions in precrisis Korea using OLS. The result showed that Korean commercial banks and merchant banking corporations had been significantly exposed to both interest rate and exchange rate risks, and that the subsequent profitability of commercial banks was significantly associated with the degree of pre-crises exposure. The results also showed that Korean case highlights the importance of up-grading financial supervision and risk as a pre-condition for successful financial liberalization.

Linbo (2004) examined efficiency versus risk in large domestic US banks descriptive statistic and discovered that profit efficiency is sensitive to credit risk and insolvency risk but not to liquidity risk or to the mix of loan products.

Empirical analyses and findings from sensual studies such as Dredhmann, Sorensen and Stringa (2008) and Dozie (2010) revealed that risk management efficiency in banks is co-determined by macroeconomic factors which vary with cycles. These macroeconomic factors have not been well integrated into the Basel guide.

Ejem (2017) on analysis of risk management on Nigerian money deposit banks(DMBs) used ECM, found that Credit Risk has made significant and negative impact on Return on Assets while Average Liquidity Ratio has not made significant impact on Return on Assets.

Kolapo, Ayeni, and Oke (2012) investigated credit risk and commercial bank's performance in Nigeria using panel data regression analysis. They found that the effect of credit risk on bank performance measured by return on assets is cross-sectionally variant. That is, the nature and managerial pattern of individual firm do not determine the impact. This is revealed by the restricted F-test under the fixed effect analysis. That loan and advances ratio (LA) coefficient exerts most significant positive effect on the profitability across the banking firms.

Okpara (2012) in his research on effects of risk on banking sector performance in Nigeria using descriptive statistics, found that the effect of credit risk on performance of banks in banking sector is roughly dicey.

Seyram and Yakubu (2013) examined the risk management practices among selected banks in Ghana with crosssectional research design and multiple regression analyses, it however unraveled the major risk management determinants which include, understanding of risk, risk identification, risk assessment and analysis, risk monitoring and controlling system. Risk monitoring and control was noted to be the most influencing variable in risk management practice among the banks. That negative relationship exists between them. 
Kargi (2011) investigated the impact of risk on the profitability of Nigerian banks, Descriptive, correlation and regression techniques were used in the analysis. Then it revealed that credit risk management has significant impact on the profitability of Nigeria banks.

Epure and Lafuente (2012) examined bank performance in the presence of risk for Costa-Rican banking industry during 1998-2007 using OLS. The results unfolded that performance improvements follow regulatory changes and that risk explains differences in banks and non-performing loans negatively affect efficiency and return on assets while the capital adequacy ratio has a positive impact on the net interest margin.

Chen and Pan (2012) examined the credit risk efficiency of 34 Taiwanese commercial banks over the period 2005-2008. Their study used financial ratio to assess the credit risk and was analyzed using Data Envelopment Analysis (DEA). The credit risk parameters were credit risk technical efficiency (CR-TE), credit risk allocative efficiency (CR-CE).The results showed that only one bank is efficient in all types of efficiencies over the evaluated periods. Overall, the DEA results show relatively low average efficiency levels in CR-TE, CR-AE and CR-CE in 2008.

Al-khomi (2011) assessed the impact of banks' banking environment on the performance of 43 commercial banks operating in 6 of the Gulf cooperation council (GCC) countries over the period 1998-2008. Employed fixed effect regression analysis, results showed that credit risk, liquidity risk and capital risk are the major factors that affect bank performance when profitability is measured by return on assets while the only risk that affects profitability when measured by return on equity is liquidity risk

Ayodele and Alabi (2014) in their study Risk management in Nigeria Banking Industry using ANOVA revealed that fraud and forgeries in banks constitute a risk factor to banks' performance and is therefore playing an adverse role in its activities. They also discovered that among the various types of risk confronting banks' performance, operation risk and credit risk are the commonest.

\section{Methodology}

\subsection{Data}

We use annual aggregated time series data for the period from 1990 to 2016. The dependent variable is return on assets while the two explanatory variables are non-performing loan ratio to total loan and average liquidity ratio. The source of data collection is Nigeria Deposit Insurance Commission (NDIC) statistical bulletin for various years. The empirical analysis is done in EViews 9.

\subsection{Method and Model}

This study employs the Autoregressive Distributive Lag Model to investigate the impact of credit and liquidity risks on the performance of Deposit Money Banks (DMBs). The study relationship is specified as follows:

$$
R O A=f(N P L R, A L R)
$$

Where;

ROA = Return on Assets, a proxy for bank performance

NPLR $=$ The ratio of non-performing loan to total loan, a proxy for credit risk

ALR =Average Liquidity Ratio, a proxy for liquidity risk

Thesimple ARDL representation of the above functional model is given as follows:

$$
R O A_{t}=\alpha_{0}+\alpha_{1} R O A_{t-1}+\alpha_{2} N P L R_{t}+\alpha_{3} N P L R_{t-1}+\alpha_{4} A L R_{t}+\alpha_{5} A L R_{t-1}+e_{t}(2)
$$

Where $\alpha_{0}=$ regression intercept, $\alpha_{1}, \alpha_{2}, \alpha_{3}, \alpha_{4}$ and $\alpha_{5}$ the regression slopes, $e_{t}=$ error term. The implication of the above ARDL model is that effect of past bank performance, which is represented by $\alpha_{1}$, is controlled for. Further, while $\alpha_{2}$ and $\alpha_{4}$ capture the current period effect of credit risk and liquidity risk respectively, $\alpha_{3}$ and $\alpha_{5}$ capture their lagged effects.

\section{Empirical Analysis}

\subsection{Stationarity Tests}

Table 1 shows the ADF unit root test results for ROA, NPLR and ALR. The optimum lag order for this test is determined by Schwarz information criterium (SIC). As we can see, while ROA series is stationary at level, both NPLR and ALR are stationary at level series. Thus, the variables have different orders of integration, justifying the use of ARDL framework.

\begin{tabular}{|c|c|c|c|c|c|c|}
\hline Variables & Lag & $\begin{array}{c}\text { ADF Test } \\
\text { Statistic }\end{array}$ & $\begin{array}{c}\text { ADF Test } \\
\text { Statistic }\end{array}$ & \multicolumn{2}{|c|}{ Critical Values } & \multirow{2}{*}{ Remarks } \\
\cline { 2 - 6 } & SIC & LEVEL & 1 st difference & $1 \%$ & $5 \%$ & \\
\hline ROA & 6 & -4.811241 & - & -3.71145 & -2.981038 & Stationary \\
\hline CR & 6 & - & -4.676422 & -3.72407 & -2.986225 & Stationary \\
\hline ALR & 6 & - & -6.23827 & -3.72407 & -2.986225 & Stationary \\
\hline
\end{tabular}

Table 1: Augmented Dickey-Fuller Unit Root Test 


\subsection{Model Estimation and Results}

Table 2 shows the estimated ARDL results for the relationship between credit risk, liquidity risk and bank performance. The optimum lag for plausible ARDL specification is determined using the Schwarz information criterion (SIC). According to this criterion, an ARDL $(1,1,0)$ model is the best description of the relationships being studied.

One striking feature of the results in Table 2 is that the lagged value of ROA is positive and statistically significant at $5 \%$ level. This implies that bank performance is autoregressive, hence, past bank performance is a significant determinant of current bank performance in Nigeria. Another striking feature of the results is that both current and previous values of non-performing loan are highly statistically significant. This implies that the effect of non-performing on bank performance extends to the next period. However, while the current period effect of non-performing loan is positive, its previous period effect is negative. The coefficients of 1.214191 and -1.204523 indicate that banks' return on assets would immediately increase by approximately $1.2 \%$ following a $1 \%$ increase in non-performing loan relative to total loan but would decrease almost by the same proportion after one year. Thus, the total effect of an increase in non-performing loan is $0.096(=1.214191-1.204523)$. Finally, the results in Table 2 shows that the relationship between average liquidity ratio and return on assets has no lagged effects. The coefficient of -0.0027 with a $p$-value of 0.9754 shows that the effect of average liquidity ratio is negative but statistically insignificant. The size of this coefficient $(-0.0027)$ also shows that the effect of average liquidity ratio is also economically insignificant.

The Adjusted R-square of 0.476 shows that the estimated ARDL $(1,1,0)$ model is moderately fitted, with the explanatory factors jointly accounting for approximately $48 \%$ of the total variance of banks' return on assets. The probability of F-statistic is 0.0012 , indicating that the estimated model is highly significant. The Durbin Watson value of 1.968 also shows that the model is free from serial correlation problem. Thus, one can conclude that our model adequately describes the relationship between credit risk, liquidity risk and bank performance.

\begin{tabular}{|c|c|c|}
\hline Variable & Coefficient & P-value \\
\hline ROA(-1) & 0.327649 & 0.0499 \\
\hline NPLR & 1.214191 & 0.0001 \\
\hline NPLR(-1) & -1.204523 & 0.0001 \\
\hline ALR & -0.002766 & 0.9754 \\
\hline Constant & 4.529186 & 0.4766 \\
\hline R-square & \multicolumn{2}{|c|}{0.560032} \\
\hline Adj. R-square & \multicolumn{2}{|c|}{0.476228} \\
\hline F-statistic & & 6.682673 \\
\hline Prob(F-statistic) & \multicolumn{2}{|c|}{0.001240} \\
\hline Durbin-Watson & \multicolumn{2}{|c|}{1.968336} \\
\hline
\end{tabular}

Table 2: ARDL Estimation Results

Table 4.3 shows the ARDL Bound cointegration test which tests for the presence of long run relationships in our empirical model. As we can see, the F-statistic is 6.403, which is greater than all the critical values at both I(0) and I(1) bounds. This clearly rejects the null hypothesis of no cointegration, implying that there is a long run relationship in our specified model.

Table 4 shows the cointegrating and long run forms of the study relationships. As this Table shows, the speed of adjustment coefficient (Cointeq $(-1)=-0.6723$, $\mathrm{p}$-value $=0.0003$ ) has the expected negative sign and is highly statistically significant. This coefficient shows that approximately $67 \%$ of the deviations from the equilibrium of bank performance with credit and liquidity risks are corrected in the next period. Further, the results show that in the short run, only the effect of non-performing loan ratio is significant, while in the long run, both non-performing loan ratio and average liquidity ratio exert insignificant effects.

\begin{tabular}{|c|c|c|}
\hline \multicolumn{3}{|c|}{ Test Statistic Value } \\
\hline \multicolumn{3}{|c|}{ F-statistic 6.403141 } \\
\hline \multicolumn{3}{|c|}{ Critical Value Bounds } \\
\hline Significance & Significance & Significance \\
\hline $10 \%$ & $10 \%$ & $10 \%$ \\
\hline $5 \%$ & $5 \%$ & $5 \%$ \\
\hline $2.5 \%$ & $2.5 \%$ & $2.5 \%$ \\
\hline $1 \%$ & $1 \%$ & $1 \%$ \\
\hline
\end{tabular}

Table 3: ARDL Bound Cointegration Test 


\begin{tabular}{|c|c|c|}
\hline \multicolumn{2}{|c|}{ Cointegrating Form } \\
\hline Variable & Coefficient & p-value \\
\hline $\mathrm{D}(\mathrm{NPLR})$ & 1.214191 & 0.0001 \\
\hline $\mathrm{D}(\mathrm{ALR})$ & -0.002766 & 0.9754 \\
\hline CointEq(-1) & -0.672351 & 0.0003 \\
\hline \multicolumn{2}{|c|}{ Cointeq $=$ ROA - (-0.0041*ALR +0.0144*NPLR +6.7363) } \\
\hline NPLR & Long Run Coefficients \\
\hline ALR & 0.014379 & 0.9520 \\
\hline Constant & -0.004114 & 0.9755 \\
\hline
\end{tabular}

Table 4: Cointegrating and Long Run Form

\section{Summary and Conclusions}

In this study, we examine the effects of credit and liquidity risks on performance of deposit money banks in Nigeria using aggregated time series data within the ARDL framework from 1990 to 2016. While credit risk is defined as the ratio of non-performing loans to total loans, liquidity risk is measured by average liquidity ratio. Bank performance is measured by return on assets.

There is evidence that bank performance is autoregressive such that a $1 \%$ increase in return on assets in the current period would lead to approximately 33\% increase in the next period return on assets. Further, there is evidence that while non-performing loan has highly significant contemporaneous and lagged effects on return on assets, the effect of average liquidity ratio is insignificant. Thus, bank performance is only affected by credit risks. We therefore argue that focusing on credit risk management would be healthy in the Nigerian banking system.

\section{References}

i. Al-khomi, R.(2011). Assessing the risk and performance of the banking sector. International Journal of Finance and Economic, (72)8.

ii. Ayodele, T.D., \&Alabi, R.O., (2014). Risk management in Nigeria banking industry. Research

iii. Journal ofFinance and Accounting.5(2):131-136.

iv. Basel Committee on Banking Supervision (1999). Principles for the management $\quad$ of credit risk, $\quad$ Ch - 4002 BASEL. Switzerland Bank for International Settlements.

v. Basel Committee on Banking Supervision (2001). Risk management practices and regulatory capital: crosssectional comparison. BASEL committee on banking supervision. Available from www.bis.org.

vi. Bessis, J.(2002). Risk management in banking. Chichester, John Wiley \& Sons.

vii. Chen, K. \& Pan, C. (2012). An empirical study of credit risk efficiency of banking industry in Taiwan. Web Journal of Chinese Management Review, 15(1), 1-16.

viii. Dozie, O. (2010). Turning Inward? Or fighting the crisis with further opening? Evidence from the

ix. Nigerian Banking System. African Centre for Economic Transformation. Accra. Ghana

x. Drehman, M., Sorensen, S. \& Stringa, M. (2008). The integrated impact of credit and interest rate risk on banks: an economic value and capital adequacy perspective. Bank of England

xi. Working Paper. No. 339.

xii. Ejem, C.A.(2017). Analysis of risk management on Nigerian money deposit banks (DMBs). Unpublished Ph.D. seminar work submitted to the department of Banking and Finance, ABSU.

xiii. Epure, M. \& Lafuente, I. (2012). Monitoring bank performance in the presence ofrisk. Barcelona GSE Working Paper Series. 61.

xiv. Gieseche, K.(2004). Credit risk modeling and valuation: an introduction, credit risk: Models and management. London, Cornell University.

xv. Gostineau, G.L. (1992). Dictionary of financial risk management. Chicago, Swiss Bank Corporation.

xvi. Halim, J.H. (2004). Interest rate and exchange rate exposure of banking institutions in pre-crisis

xvii. Korea. Applied Economics, 36(13), 409-19.

xviii. Heffernan, S. (1996). Modern banking in theory and practice. Chichester. John Wiley and Sons. International Journal of Management and Sustainability, 2014, 3(5), 295-306.

xix. Joel, B. (2009). Risk Management in Banking, Second Edition.Lagos, Macmillan Publishers.

xx. Kargi, H.S. (2011). Credit Risk and the Performance of Nigerian banks. MSc seminar Paper Submitted to the Ahmadu Bello University, Zaria.

xxi. Kolapo, T.F., Ayeni, R.K.,\& Oke, M.O. (2012). Credit risk and commercial performance in

xxii. Nigeria. A Management Research, 2(2), 31-38.

xxiii. Linbo Fan, L. (2004). Efficiency versus risk in large domestic US. Managerial Finance,30(9).1-19.

xxiv. NDIC (2016). Annual Reports and accounts of Banks Submitted to NDIC.

xxv. Njogo, B.O. (2012). Risk management in the Nigerian banking industry. Kuwait Chapter of

xxvi. Arabian Journal of Business and Management Review. 1(11).

xxvii. Nwankwo, G.O. (1991). Bank management principles and practice. Lagos, Malt- house Press Limited.

xxviii. Nzotta, M.S (2002). Corporate financial decisions. Owerri, Oliverson Industrial Publishers.

xxix. Nzotta, S.M. (2004). Money, banking and finance (theory and practice). Owerri, Hudson-Jude My Publishers. 
xxx. Ogunleye, R.W. (2001). Sensitivity of bank stock returns to market and interest rate risk: An empirical investigation. NDIC, Quarterly Review, 1(1-2), 57-77.

xxxi. Okpara, G. C. (2012). Analysis of the effect of risk on the banking sector performance in Nigeria. International Journal of Economics and Finance, 2(4)

xxxii. Olowe R.A. (1998). Financial Management: Concepts, Analysis and Capital Investments. Lagos:

xxxiii. Brierly Jones Nig Ltd.

xxxiv. Owojori, A.A., Akintoye, I. R., \& Adidu, F.A. (2011). The challenge of risk management Nigerian banks in the post consolidation era. Journal of Accounting and Taxation,3(2),23-31.

xxxv. Owualla, S.I. (2000). Principles of financial management. Lagos: G. Mag Investment Ltd.

xxxvi. Pandey, I.M. (2004). Financial Management. New Delhi: Vikas Publishing House. PVT.

xxxvii. Rose \& Hudgins (2010). Bank management and financial service. London, McGrawHill.

xxxviii. Saunders, A. \& Cornett, M. M. (2006). Financial institutions management: A risk management approach. New York, McGrawHill.

xxxix. Seyram, P.K., \& Yakubu, A.S. (2013). Risk management practices among commercial banks in Ghana. European Journal of Business and Management, 5(20), 185-190.

xl. Soludo C. C. (2007). Financial system strategy 2020, the next development threshold. A text of speech delivered at the Nigeria Television Authority 2nd National Lecture Series, held in Abuja.

xli. Umoh, P.N. (2002) An overview of risk management practice in the Nigeria Banking Industry. NDIC, 12(4), 36-46.

xlii. Umoh P.N.(1994). Bank loans' recovery: the roles of the regulatory/ supervisory authorities. Judiciary Enforcement Agencies and the Press, NDIC Quarterly.4(3).8. 